\section{耍 Heighten Science \\ P U B L I C I T I O N S Corporation ISSN 2575-0194}

\title{
Lemongrass tea consumption and changes in Acid-Base Balance and Electrolyte homeostasis
}

\author{
Christopher E Ekpenyong* \\ Department of Physiology, Faculty of Basic Medical Sciences, University of Uyo, Uyo, Nigeria
}

\begin{abstract}
*Address for Correspondence: Dr. Christopher Edet Ekpenyong, Department of Physiology, Faculty of Basic Medical Sciences, University of Uyo, Uyo, Nigeria, Email: chrisvon200@yahoo.com; chrisvon300@yahoo.com
\end{abstract}

Submitted: 24 December 2018

Approved: 28 December 2018

Published: 31 December 2018

\section{Copyright: (C) 2018 Ekpenyong CE, et al. This} is an open access article distributed under the Creative Commons Attribution License, which permits unrestricted use, distribution, and reproduction in any medium, provided the original work is properly cited

Keywords: Cymbopogon citratus; $\mathrm{pH}$ changes; Electrolyte disturbance

Check for updates

\section{Abstract}

The consumption of dietary herbs and supplements may be associated with several physiological consequences including, but not limited to disturbances of acid-base homeostasis, minerals and electrolytes wasting, gastrointestinal disturbances as well as hemodynamic changes. Plants food based nutritional studies are important for assessing the effect of plants on human health and wellbeing. The aim of this study was to assess the changes in acid-base status and electrolyte homeostasis following the consumption of lemongrass tea. The acute and sub-chronic effects of infusions prepared from 2, 4, and $8 \mathrm{~g}$ lemongrass leaf powder on serum and urinary $\mathrm{pH}$, and electrolytes levels were assessed in 105 subjects using an interventional study design. The results post-treatment were compared with baseline values.

Plasma pH decreased from baseline value of $7.37 \pm 0.02$ to $7.20 \pm 0.03$, and $7.30 \pm 0.02$ at days 10 and 30 respectively for participants treated with infusion prepared from $2 \mathrm{~g}$ of lemongrass leaf powder. For those treated with infusion prepared from $4 \mathrm{~g}$ of lemongrass leaf powder, plasma $\mathrm{pH}$ decreased from baseline value of $7.35 \pm 0.02$ to $7.22 \pm 0.02$ and $7.29 \pm 0.02$ at days 10 and 30 respectively.

Treatment with infusion prepared from $8 \mathrm{~g}$ of lemongrass leaf powder caused a decrease in plasma pH from baseline value of $7.38 \pm 0.02$ to $7.15 \pm 0.02$ and $7.18 \pm 0.02$ at days 10 and 30 respectively. Corresponding changes in urinary $\mathrm{pH}$ were also observed. Furthermore, at days 10 and 30, plasma protein concentrations increased significantly $(p<0.05)$ in subjects treated with infusion prepared from $8 \mathrm{~g}$ lemongrass leaf extract. There were also significant increases $(p<0.05)$ in urinary volume, urination frequency, and urinary electrolytes levels within the same period.

The consumption of lemongrass tea may be associated with changes in acid-base balance and electrolyte homeostasis due to its varied biological constituents and their activities.

\section{Introduction}

Disturbances in acid-base balance and electrolyte homeostasis associated with the consumption of dietary herbs are common [1], but underreported [2]. Such cases, if reported, could be of public health interest, as they may serve to alter both consumers' and healthcare practitioners' opinions. Accordingly, Luyckx et al. [3], report metabolic acidosis in $80.8 \%$ and volume depletion with associated electrolyte derangement in $62.8 \%$ of patients with renal failure following the consumption of a particular herbal diet. Similarly, Ifudu and Friedman [2], report a case of type 4 renal tubular acidosis with associated hyperkalemia in a patient who ingested a particular herbal medicine. Other reported cases include hyperkalemia induced by noni (Morinda citrifolia) juice in a patient with renal insufficiency [4]. Gerson cancer therapy-induced hyperkalemia in patients with Hodgkin lymphoma [5], aristolochic acid-induced hypokalemic paralysis, hypokalemia with renal potassium wasting, hyperchloremic metabolic acidosis, hypophosphatemia with hyperphosphaturia, hypouricemia with hyperuricosuria and glycosuria (i.e., Fanconi syndrome) [6] and licorice-induced hypokalemia in a 
patient with prostate cancer [7]. The abovementioned cases are merely a fraction of all of such cases, as there are likely many more cases unreported by both consumers and practitioners. In addition, they do not include non-hospitalized cases and underdiagnosed cases, particularly in developing countries lacking accurate/advanced diagnostic facilities. According to Ko [8], approximately 32\% of 260 alternative medicine products analyzed contained potentially harmful undeclared substances [2]. Moreover, Haller et al. [9], report that only $40 \%$ of people who used alternative medicine products inform their primary care physicians. Although the underlying mechanisms by which some alternative medicine products alter acid-base balance and electrolyte homeostasis remain debatable, current evidence suggests the causal roles of various bioactive constituents and their pharmacodynamic and pharmacokinetic interactions with the body's homeostatic mechanisms. For instance, noni juice causes hyperkalemia owing to its high potassium content (56.3 mEq/L) [4], whereas mourning cypress (Cupressus funebris Endl.) extract causes acute renal failure, acute hepatic failure, autoimmune hemolytic anemia, and thrombocytopenia owing to its high flavonoids content [10]. Several other herbs with laxative activities also cause hypokalemia with associated metabolic alkalosis [11].

Likewise, herbs with known diuretic activity may induce changes in acid-base balance as well as water and electrolyte homeostasis partly because of the interaction of some of their bioconstituents with various physiological systems responsible for the body's acid-base and electrolyte homeostasis. One such herb with known diuretic action but without adequate documented evidence for its effect on acid-base homeostasis and electrolyte balance in human is lemongrass (Cymbopogon citratus (C. citratus), family: Poaceae), it is a widely distributed tall aromatic perennial plant with thin green leaves approximately $90 \mathrm{~cm}$ long and $1.5 \mathrm{~cm}$ wide [12]. The leaves contain various bioactive substances including phytochemicals, macronutrients, minerals, vitamins, and essential oils. Citral, a monoterpene aldehyde, is the predominant constituent, and pharmacologically and physiologically important component of $C$. citratus essential oil. C. citratus has a century-long record of extensive therapeutic, nutritional, and cosmetic usage. It is used in alternative medicine for its anti-inflammatory, anticarcinogenic, antimicrobial, antioxidant, antidiabetic, antidyslipidemic, antiplatelet, antispasmodic, antipyretic, analgesic, sedative, and cardio-protective properties [13]. Meanwhile, it is also used in traditional cuisines including dishes, baked foods, and confections; it is consumed as tea in Brazil and in soft drinks in Peru [14]. It is also preferred by many consumers because of its physiochemical characteristics including taste, lemony aroma, and color [15]. Regarding cosmetic uses, the plant is used in perfumes, soaps, detergents, and body creams [16]. Recent evidence supports its use in food preservation because of its significant broad-spectrum antimycotic potency, which can remain for 210 days of storage [17], as well as its fungitoxic, fungistatic, antimycotoxin, and nonphytotoxic properties [18]. However, whether C. citratus leaf infusion interferes with plasma $\mathrm{pH}$, water, and electrolyte balance has not yet been documented despite its long history of edible, therapeutic, and cosmetic uses. Plant food based nutritional studies are important for assessing the effect of plants on human health and wellbeing. Therefore, the present study aimed to determine the effects of $C$. citratus leaf infusion on acid-base balance and electrolyte homeostasis in normal humans.

\section{Materials and Methods}

\section{Selection of participants}

One hundred and five participants (55males and 50females) were qualified to participate in this survey. They provided written informed consent to validate their participation. All participants underwent a thorough pre-survey medical screening that was performed by a Medical Doctor to ensure medical fitness and to exclude those who did not meet the inclusion criteria. The exclusion criteria were as follows: previous history of hypersensitivity reaction to any of the lemongrass constituents, 
use of drugs that may interfere with the effect of the extract, and history of kidney or liver disease. Other exclusion criteria include disorders of hematopoietic system (such as sickle cell disease), in appropriate age ( $<18$ and $>35$ years), pregnancy or lactation and failure to satisfy the pre-trial clinical and biochemical assessment.

The preliminary medical screening included obtaining past medical history, a lifestyle assessment (smoking status, drinking, diet, drug history and physical activity status), blood pressure (BP), heart rate (HR), weight, blood glucose level, full blood count and platelet count, and urine and blood indices of renal and hepatic function. The participants were advised to avoid excessive physical activity and ingestion of drugs or alcohol, and to remain on their regular diet, but to avoid high saponins and polyphenol-rich foods/vegetables. The study design and experimental protocols were approved by the Institutional Human Ethics Committee.

\section{Preparation of extract for phytochemical and nutritional analysis}

C. citratus leaves were harvested fresh from a local farm in Uyo, Akwa Ibom State, Nigeria few days prior to utilization. The leaves were identified and authenticated by a taxonomist in the Department of Botany at the University of Uyo, Nigeria. The leaves were rinsed, sundried and pulverized into powder using electric blender to yield a weight of $200 \mathrm{~g}$. The leaf powder was soaked in a container with $2 \mathrm{~L}$ of hot water and allowed to stand for approximately $8 \mathrm{hrs}$. Thereafter, the solution was filtered using $\mathrm{N}_{0} .2$ Whatman filter paper. The filtrate was evaporated by heating in a water bath at $40^{\circ} \mathrm{C}$ to obtain the solid extract. The solid extract was weighed (ACS-ZE14 Surgifriend Medical Ltd, England) to obtain a yield of $70 \mathrm{~g}(35 \% \mathrm{w} / \mathrm{w})$ which was then stored in clean bottles at room temperature and later used for phytochemical and nutritional analysis.

\section{Administration of infusion}

The participants were divided into 3groups ( $\mathrm{n}=35$ /group). Each group received infusions prepared from 2, 4, or $8 \mathrm{~g}$ of $C$. citratus leaf powder, in $150 \mathrm{ml}$ of hot water, given once daily at scheduled time (between $10 \mathrm{am}-3 \mathrm{pm}$ ) for 30 days. This infusion was prepared in this manner to correspond to the way in which lemongrass tea is usually prepared by the population. The dose range employed was adapted from previous human studies in which participants showed no obvious clinical or biochemical evidence of toxicity $[19,20]$. Also, a pilot study conducted on 10 volunteers using infusions prepared from 2, 4, 8 and $10 \mathrm{~g}$ of $C$. citratus leaf powder in $150 \mathrm{ml}$ of hot water showed no evidence of adverse/toxic effects, based on the results of the tolerability assessment. These included a range of clinical and laboratory tests, including test for renal function (serum creatinine and clearance rate ( $\mathrm{Cr}$ ), liver function (Aminotransferase activity), serum urea levels and hematological indices. The participants were also examined for presence of jaundice, or pallor (evidence of hepatotoxicity and hemolysis), and for evidence of abnormal skin reactions. The participants were also instructed to report any unusual symptom on the symptomatology and fluid intake assessment questionnaire including lightness of the body, headache, dizziness, sweating, frequent maturation, belching, dyspepsia, diarrhea, constipation, vomiting and palpitation.

\section{Samples collection and biochemical analysis}

Venous blood samples were drawn from all participants on the scheduled days (days 0,10 and 30) in 10ml EDTA and dry tubes for plasma and serum collection respectively. Blood samples were immediately stored in cold boxes and transferred to department of chemical pathology, University of Uyo Teaching Hospital where the biochemical analysis was done using standard procedures.

Twelve-hour urine samples were collected from all participants between the hours of $6 \mathrm{pm}$ and $6 \mathrm{am}$, at days 0,10 , and 30 after initiation of the study. The volume of the urine was measured with a calibrated cylinder, while the 24 -h urination frequency was reported in a chart designed by the authors. The $\mathrm{Na}^{+}$and $\mathrm{K}^{+}$concentrations in the urine 
were determined by Flame Photometry ("Jencon PEP 9", Jencons Scientific Limited, Bedfordshire, UK), $\mathrm{Ca}^{2+}$ was measured by atomic absorption spectrophotometry (Jarrel-Arh Model 82-36, UK), and $\mathrm{Cl}^{-}$was measured using an ion selective meter (Orion 730", Orion Research Inc. Boston, USA). Urinary pH was measured using a digital pH meter (Model E9610, Equiptronics, England), while glucose and protein were measured using urine reagent test strips (Combi 9, Macherey-Negrel, Germany). On the days when urine specimens were collected (i.e., days 0,10 , and 30 ), fluid and food intake were restricted between the time of administration of the infusion and collection of the final urine sample (6pm to $6 \mathrm{am})$.

\section{Statistical analysis}

Data (mean \pm SEM) were analyzed using one-way analysis of variance (ANOVA). Differences were considered statistically significant at $\mathrm{P}<0.05$. All analyses were performed using the Statistical Package for the Social Sciences (SPSS 20.0).

\section{Results}

The phytochemical constituents of $C$. citratus leaf extract revealed a relatively high concentration of saponins; moderate concentrations of tannins, flavonoids, and phenols; and relatively low concentrations of alkaloids, deoxysugars, and anthraquinones. The nutrient constituents of $C$. citratus leaf extract detected include moisture, crude protein, fiber, fat, carbohydrates, and micronutrients including $\mathrm{K}^{+}, \mathrm{Na}^{+}$, $\mathrm{Ca}^{2+}, \mathrm{F}^{2+}, \mathrm{Mg}^{2+}, \mathrm{Cu}, \mathrm{Mn}, \mathrm{Se}, \mathrm{Zn}$, vitamin $\mathrm{C}$, and folate. Regarding the baseline demographic and clinical characteristics of the study participants, most (52\%) were males and were between 18 and 35 years old.

The participants' basic characteristics were as follows: mean weight, $60.74 \pm 1.93$ $\mathrm{kg}$; body mass index, $23.46 \pm 0.75 \mathrm{~kg} / \mathrm{m}^{2}$; systolic blood pressure, $120.53 \pm 1.89 \mathrm{mmHg}$; diastolic blood pressure, $74.64 \pm 1.62 \mathrm{mmHg}$; mean arterial pressure, $85.69 \pm 1.13$ $\mathrm{mmHg}$; heart rate, $77.71 \pm 1.99$ beats $/ \mathrm{min}$; mean pulse pressure, $45.89 \pm 1.04 \mathrm{mmHg}$; glomerular filtration rate, $99.88 \pm 1.52 \mathrm{mlmin}$; and mean respiratory rate, $18.56 \pm$ $1.52 \mathrm{~mL} / \mathrm{min}$. There were no significant changes in serum concentrations of $\mathrm{K}^{+}, \mathrm{Na}^{+}$, $\mathrm{Cl}^{-}$, or $\mathrm{HCO}_{3}{ }^{-}$at days 10 or 30, (Table 1). In addition, serum $\mathrm{Ca}^{2+}$ levels did not differ significantly from baseline, but decreased significantly at day 30 in those treated with infusion prepared from $8 \mathrm{~g}$ leaf powder for 30 days $(p<0.05)$.

Plasma pH decreased from baseline value of $7.37 \pm 0.02$ to $7.20 \pm 0.03$, and 7.30 \pm 0.02 at days 10 and 30 respectively for participants treated with infusion prepared from $2 \mathrm{~g}$ of $C$. citratus leaf powder. For those treated with infusion prepared from $4 \mathrm{~g}$ of C. citratus leaf powder, plasma $\mathrm{pH}$ decreased from baseline value of $7.35 \pm 0.02$ to 7.22 \pm 0.02 and $7.29 \pm 0.02$ at days 10 and 30 respectively.

Table 1: Acute (10 Days) and sub-chronic (30 days) effects of infusions prepared from C. citratus powder on serum electrolytes and $\mathrm{Ph}$.

\begin{tabular}{|c|c|c|c|c|c|c|c|}
\hline $\begin{array}{c}\text { Duration/ } \\
\text { concentration }\end{array}$ & $\underset{\text { mmol/L }}{\mathbf{K}^{+}}$ & $\begin{array}{c}\mathrm{Na}^{+} \\
\text {mmol/L }\end{array}$ & $\begin{array}{l}\mathrm{Ca}^{2+} \\
\text { mmoll/ }\end{array}$ & $\underset{\text { mmol/L }}{\mathrm{Cl}^{-}}$ & $\begin{array}{c}\mathrm{HCO}_{3} \\
\mathrm{mmol} / \mathrm{L}\end{array}$ & pH & $\begin{array}{l}\text { Protein } \\
\text { g/dl }\end{array}$ \\
\hline $\begin{array}{c}\text { Control } \\
2 g \\
4 g \\
8 g\end{array}$ & $\begin{array}{l}3.98 \pm 0.06 \\
3.84 \pm 0.04 \\
3.93 \pm 0.07\end{array}$ & $\begin{array}{l}138.69 \pm 0.83 \\
138.14 \pm 0.33 \\
136.66 \pm 0.64\end{array}$ & $\begin{array}{l}2.42 \pm 0.04 \\
2.54 \pm 0.04 \\
2.67 \pm 0.06\end{array}$ & $\begin{array}{c}101.80 \pm 2.28 \\
102.51 \pm 0.42 \\
103.11 \pm 0.61\end{array}$ & $\begin{array}{l}24.37 \pm 0.25 \\
23.86 \pm 0.20 \\
23.77 \pm 015\end{array}$ & $\begin{array}{l}7.37 \pm 0.02 \\
7.35 \pm 0.02 \\
7.38 \pm 0.02\end{array}$ & $\begin{array}{l}68.26 \pm 0.53 \\
68.70 \pm 0.62 \\
68.76 \pm 0.66\end{array}$ \\
\hline Acute & \multirow[b]{2}{*}{$3.99 \pm 0.38$} & & \multirow[b]{2}{*}{$2.56 \pm 0.03$} & \multirow[b]{2}{*}{$100.86 \pm 2.31$} & \multirow[b]{2}{*}{$24.29 \pm 0.24$} & \multirow[b]{2}{*}{$7.20 \pm 0.03$} & \multirow[b]{2}{*}{$68.29 \pm 0.72$} \\
\hline $2 \mathrm{~g}$ & & $138.91 \pm 0.46$ & & & & & \\
\hline $4 g$ & $4.29 \pm 0.07$ & $140.60 \pm 0.72$ & \multirow{2}{*}{$\begin{array}{c}2.57 \pm 0.04 \\
2.88 \pm 0.015^{c}\end{array}$} & $102.11 \pm 0.49$ & $24.09 \pm 0.26$ & $7.22 \pm 0.02$ & $68.77 \pm 0.70$ \\
\hline $8 g$ & $4.01 \pm 0.06$ & $139.26 \pm 0.57$ & & $102.91 \pm 0.60$ & $24.01 \pm 0.24$ & $7.15 \pm 0.02$ & $75.78 \pm 0.52^{a}$ \\
\hline $\begin{array}{c}\text { Sub-chronic } \\
2 \mathrm{~g}\end{array}$ & $3.89 \pm 0.04$ & $138.60 \pm 0.21$ & $2.30 \pm 0.04$ & $100.29 \pm 2.31$ & $24.20 \pm 0.28$ & $7.30 \pm 0.02$ & $69.46 \pm 0.98$ \\
\hline $4 \mathrm{~g}$ & $3.84 \pm 0.05$ & $138.02 \pm 0.26^{b}$ & \begin{tabular}{l|l|} 
& $2.37 \pm 0.03$
\end{tabular} & $101.71 \pm 0.25$ & $24.03 \pm 0.23$ & $7.29 \pm 0.02$ & $69.80 \pm 0.75$ \\
\hline $8 g$ & $3.85 \pm 0.04$ & $133.91 \pm 0.38^{b}$ & $2.47 \pm 0.05^{\mathrm{ab}}$ & $103.00 \pm 0.36$ & $23.83 \pm 0.23$ & $7.18 \pm 0.02$ & $77.12 \pm 0.51^{a}$ \\
\hline
\end{tabular}


Treatment with infusion prepared from $8 \mathrm{~g}$ of $C$. citratus leaf powder caused a decrease in plasma pH from baseline value of $7.38 \pm 0.02$ to $7.15 \pm 0.02$ and $7.18 \pm 0.02$ at days 10 and 30 respectively.

Urinary $\mathrm{pH}$ decreased from baseline value of $5.57 \pm 0.24$ to $4.59 \pm 0.19$ and 4.02 \pm 0.14 at days 10 and 30 respectively for participants treated with infusion prepared from $2 \mathrm{~g}$ of $C$. citratus leaf powder.

Treatment with infusion prepared from $4 \mathrm{~g}$ of $C$. citratus leaf powder decreased urinary $\mathrm{pH}$ from the baseline value of $5.88 \pm 0.19$ to $5.00 \pm 0.23$ and $4.11 \pm 0.16$ at days 10 and 30 respectively.

Furthermore, in participants treated with infusion prepared from $8 \mathrm{~g}$ of C. citraus leaf powder, urinary $\mathrm{pH}$ decreased from baseline value of $5.20 \pm 0.17$ to $4.99 \pm 0.11$ and $5.01 \pm 0.18$ at days 10 and 30 respectively. Serum protein increased in all groups, but the increases were only significant among those treated with infusion prepared from $8 \mathrm{~g}$ for 10 and 30 days (Table 1 ). Urinary $\mathrm{K}^{+}$and $\mathrm{Na}^{+}$concentrations increased significantly $(p<0.05)$ at day 10 . By day $30, \mathrm{~K}^{+}$and $\mathrm{Na}^{+}$concentrations decreased, but the decrease in urinary $\mathrm{Na}^{+}$concentration was significant only among those treated with infusions prepared from 2 or $8 \mathrm{~g}$ C. citratus powder. Urinary $\mathrm{Ca}^{2+}$ and $\mathrm{Cl}^{-}$ concentrations increased significantly at both days 10 and 30, except in those treated with infusion prepared from $8 \mathrm{~g}$ C. citratus leaf powder for 10 days, which did not differ significantly from baseline. In addition, 24-hour urination frequency increased significantly in all groups except in participants treated with infusion prepared from 2 g C. citratus leaf powder for 30 days. Twelve-hour urine volume increased significantly in all treatment groups by day $10(p<0.05)$. After 30 days, urine output remained elevated in the participants treated with infusions prepared from 4 or $8 \mathrm{~g}$ C. citratus leaf powder (Table 2). The renal fractional excretion of electrolytes (i.e., $\mathrm{K}^{+}, \mathrm{Na}^{+}, \mathrm{Ca}^{2+}$, and $\mathrm{Cl}^{-}$) and organic substances (i.e., urea, uric acid, and creatinine) generally increased significantly in most of groups in both study phases.

\section{Discussion}

Under normal steady-state metabolic conditions, the human body tends to tightly control pH from 7.35-7.45 (mean: 7.4) by respiratory excretion of carbon dioxide and renal excretion of non-carbonic acids or bases [21]. Even slight deviations can lead to serious even life-threatening metabolic derangement [22]. The results of the present study indicate $C$. citratus leaf extract decreased plasma and urinary $\mathrm{pH}$ below the baseline values and the limit of the respective reference ranges. Although the mechanism(s) by which $C$. citratus leaf extract causes these changes is unknown, the results of the phytochemical analysis of the extract in the present and previous studies [22-24], show the presence of several phytoactive constituents (i.e., saponins,

\begin{tabular}{|c|c|c|c|c|c|c|}
\hline $\begin{array}{c}\text { Duration/ } \\
\text { Concentration }\end{array}$ & $\underset{\mathrm{mmol} / \mathrm{L}}{\mathbf{K}^{+}}$ & $\underset{\mathrm{mmol} / \mathrm{L}}{\mathrm{Na}^{+}}$ & $\underset{\mathrm{mmol} / \mathrm{L}}{\mathrm{Ca}^{2+}}$ & $\underset{\mathrm{mmol} / \mathrm{L}}{\mathrm{Cl}^{-}}$ & pH & $\begin{array}{l}24 \mathrm{hr} \text { urination } \\
\text { frequency }\end{array}$ \\
\hline $\begin{array}{c}\text { Control } \\
2 \mathrm{~g} \\
4 \mathrm{~g} \\
8 \mathrm{~g}\end{array}$ & $\begin{array}{l}40.83 \pm 1.87 \\
39.40 \pm 1.37 \\
37.71 \pm 1.68\end{array}$ & $\begin{array}{l}160.63 \pm 5.57 \\
117.94 \pm 8.56 \\
135.63 \pm 8.20\end{array}$ & $\begin{array}{l}11.78 \pm 3.87 \\
16.25 \pm 2.97 \\
11.95 \pm 2.84\end{array}$ & $\begin{array}{r}130.34 \pm 6.37 \\
147.80 \pm 6.44 \\
137.23 \pm 7.46\end{array}$ & $\begin{array}{l}5.57 \pm 0.24 \\
5.88 \pm 0.19 \\
5.20 \pm 0.17\end{array}$ & $\begin{array}{l}6.42 \pm 0.24 \\
5.06 \pm 0.20 \\
6.02 \pm 0.28\end{array}$ \\
\hline $\begin{array}{c}\text { Acute } \\
2 \mathrm{~g}\end{array}$ & $58.57 \pm 3.18^{a}$ & $170.37 \pm 8.02^{a^{\star}}$ & $13.69 \pm 1.83^{a}$ & $198.80 \pm 8.47^{a}$ & $4.59 \pm 0.19^{a}$ & $7.08 \pm 0.22^{\mathrm{a}}$ \\
\hline $4 g$ & $52.87 \pm 2.87^{a}$ & $141.89 \pm 5.53^{\mathrm{ab}}$ & $20.38 \pm 2.30^{\mathrm{ab}}$ & $206.97 \pm 3.35^{a}$ & $5.00 \pm 0.23^{a}$ & $7.04 \pm 0.37^{a}$ \\
\hline $8 g$ & $44.06 \pm 3.06^{\mathrm{abc}}$ & $140.06 \pm 7.20^{\mathrm{b}}$ & $12.86 \pm 1.86^{c}$ & $181.51 \pm 11.72^{\mathrm{ac}}$ & $4.99 \pm 0.11$ & $7.02 \pm 0.34^{\mathrm{a}}$ \\
\hline $\begin{array}{c}\text { Sub-chronic } \\
2 \mathrm{~g}\end{array}$ & $37.67 \pm 0.39$ & $127.14 \pm 8.21^{\mathrm{a}}$ & $17.13 \pm 2.26^{\mathrm{a}}$ & $190.23 \pm 7.43^{a}$ & $4.02 \pm 0.14^{\mathrm{a}}$ & $6.56 \pm 0.25$ \\
\hline $4 \mathrm{~g}$ & $37.40 \pm 1.85$ & $116.00 \pm 6.73$ & $20.43 \pm 2.99^{a}$ & $174.60 \pm 8.44^{\mathrm{a}}$ & $4.11 \pm 0.16^{a}$ & $6.74 \pm 0.31^{\mathrm{a}}$ \\
\hline $8 g$ & $36.54 \pm 0.65$ & $126.11 \pm 7.70^{\mathrm{a}}$ & $17.05 \pm 2.54^{\mathrm{a}}$ & $162.94 \pm 8.16^{\mathrm{ac}}$ & $5.01 \pm 0.18^{b c}$ & $8.00 \pm 0.22^{\mathrm{abc}}$ \\
\hline
\end{tabular}


tannins, flavonoids, alkaloids, anthraquinones, etc.) and nutrients (i.e., protein, carbohydrates, electrolytes, and minerals). Several studies show that some of these bioactive constituents interfere either individually or synergistically with enzyme/ transport systems (i.e., $\mathrm{Na}^{+}-\mathrm{K}^{+}$ATPase and alpha epithelial $\mathrm{Na}^{+}$channel $[\alpha \mathrm{ENaC}]$ mRNA) responsible for the reabsorption of these electrolytes, $\mathrm{H}^{+}$, and water in the renal tubules, leading to perturbed acid-base and electrolyte homeostasis [25,26].

De Souza et al. [27], report that saponin inhibits $\mathrm{Na}^{+}-\mathrm{K}^{+}$ATPase in a manner similar to but stronger than furosemide, a standard loop diuretic. Rhiouani et al. [28], studied the effects of saponins from Hermiaria glabra on blood pressure and renal function in rats and conclude chronic oral administration of saponins decreases arterial blood pressure and affects salt and water transport in renal tubules. Meanwhile, Jouad et al. [29], report that flavonoids significantly increase urinary $\mathrm{Na}^{+}, \mathrm{K}^{+}$, and $2 \mathrm{Cl}^{-}$concentrations in a manner similar to that of furosemide. Recent experimental studies by Hiwatashi et al. [30] and Chen et al. [31], demonstrate the inhibitory effect of saponins on the reninangiotensin-aldosterone system (RAAS), a key regulator of blood pressure, acid-base balance, and fluid volume in the body [32]. Such inhibitory actions could have extended to affect the aldosterone-sensitive $\mathrm{Na}^{+}$channels located on the renal cortical collecting tubules; this would consequently decrease the number of open $\mathrm{Na}^{+}$channels, which would increase $\mathrm{Na}^{+}$excretion, $\mathrm{K}^{+}$retention, and associated acid-base and electrolyte changes observed in the present study. This notion is supported in a study by Aoi et al. [33], who report that quercetin, a flavonoid (also found in C. citratus) inhibits $\alpha \mathrm{ENaC}$ mRNA expression in the kidneys. Lee and Chen [10], report biochemical and clinical evidence of flavonoid-induced biochemical and metabolic derangement after ingestion of a flavonoid-rich extract of $C$. funebris (mourning cypress). Furthermore, the consumption of $C$. citratus leaf extract is reported to be associated with metabolic derangement [12].

Tarkang et al. [12], report increased blood urea nitrogen and mild tubular distortion in the kidneys after the administration of $C$. citratus ethanol extract for 28 days. Compared to the controls, serum creatinine levels suggested a non-renal cause of the derangement; this further implicates the action of $C$. citratus phytoactive compounds including saponins and flavonoids, which are known for their adverse metabolic effects. Collectively, considering this consistent empirical evidence, it can be concluded that the metabolic derangement observed in the present study is corollary of the bioactive constituents in the lemongrass leaf extracts. This is supported by previous studies evaluating these compounds and reporting similar results. However, it is noteworthy that these effects are not universal. Besides the aforementioned mode of action, available evidence also implicates the pathophysiological role of some of C. citratus leaf extracts' acid-forming constituents including the biologically activepeptides derived from its high protein content. Interestingly, the high protein content in $C$. citratus leaf extracts has been repeatedly acknowledged by several investigators. In parallel studies, Oloyede [24], Akande et al. [34] and Arhoghro and Kpomah [35], report high protein concentrations in lemongrass leaf extracts. Furthermore, Tarkang et al. [12] report a significant increase in plasma protein in experimental animals fed with $C$. citratus leaf extract for 28 days.

The detection of a substantial amount of protein in our experimental leaf extract and the increase in plasma protein in participants treated with infusions prepared from $8 \mathrm{~g}$ C. citratus leaf powder for 10 and 30 days in the present study corroborate the results of the abovementioned studies. Therefore, without any contrary evidence, the changes in acid-base balance observed in the present study could be partly associated with the high protein content of the lemongrass leaf extract. This assertion is supported by the fact that relatively high dietary protein intake can generate substantial fixed acids, leading to acidemia due to the excess of sulfuric anions produced by the catabolism of the sulfur amino acids[36] Indeed, Aftab et al. [26] report high levels of sulfur, 
iron, phosphate, and aluminum $(>1 \%)$ in their lemongrass sample compared to other trace elements $(<1 \%)$; in the present study, we obtained a $\mathrm{pH}$ of $4.5-5.35$ for our experimental sample. These results collectively indicate the acidogenic potential of lemongrass leaf extract.

Another potential mechanism by which the high protein content of $C$. citratus extract could derange acid-base balance is through its inhibitory action on the RAAS. Several studies show angiotensin-converting enzyme inhibitory peptides derived from food, particularly those with high protein contents, can act as potential inhibitors of angiotensin II-mediated secretion of aldosterone from the adrenal cortex [30,31,37] Such actions could interfere with aldosterone-sensitive $\mathrm{Na}^{+}$channels and by extension, impede $\mathrm{Na}^{+}$reabsorption, and $\mathrm{K}^{+}$and $\mathrm{H}^{+}$secretion. Retention of $\mathrm{H}^{+}$and $\mathrm{K}^{+}$could lead to acidosis and hyperkalemia with associated natriuresis as was observed in the present study. Similarly, the decrease in $\mathrm{K}^{+}$in the subchronic phase to almost baseline levels signifies the adaptive role of the kidneys to acute $\mathrm{K}^{+}$loading. Surprisingly, despite the changes in serum $\mathrm{H}^{+}$concentration, serum $\mathrm{HCO}_{3}{ }^{-}$levels remained unchanged, and urinary $\mathrm{HCO}_{3}^{-}$was below detection limit, whereas urinary $\mathrm{pH}$ decreased below baseline.

These findings are probably indicative of the adaptive changes in renal function in response to acid insult [38]. In acidosis, the kidneys do not excrete $\mathrm{HCO}_{3}{ }^{-}$into urine but reabsorb all of it and even produce new $\mathrm{HCO}_{3}{ }^{-}$, which is added to the extracellular fluid. The kidneys consequently reduce the extracellular fluid $\mathrm{H}^{+}$concentration through 3 functional mechanisms: hydrogen secretion, re-absorption of filtered $\mathrm{HCO}_{3}{ }^{-}$, and production of new $\mathrm{HCO}_{3}{ }^{-}$. These mechanisms occur in virtually all parts of the renal tubules except the ascending thin limbs of the loops of Henle. These could explain the non-significant changes in plasma $\mathrm{HCO}_{3}{ }^{-}$levels in both phases of the present study and are consistent with previous studies suggesting plasma $\mathrm{HCO}_{3}{ }^{-}$levels may be normal even when acidosis is present [39]. The slight increase in plasma $\mathrm{pH}$ in the subchronic phase of the study (although still below baseline) is consistent with a previous study showing that acute acid loading may only temporarily disrupt acid-base equilibrium, while the body acid-base maintenance mechanisms (i.e., buffers, respiratory, and renal) attempt to restore a steady-state condition [39]. However, chronic perturbation occurs when metabolism of the diet repeatedly releases non-carbonic acids into the systemic circulation in amounts exceeding the amount of base released concomitantly. This hypothesis explains the partial reversal of plasma $\mathrm{pH}$ to baseline level in the subchronic phase of the present study.

The decrease in urinary $\mathrm{pH}$ levels in both study phases demonstrates the kidneys' role in urine acidification to rid the body of excess acid load. This response includes the reduction if not the elimination of all $\mathrm{HCO}_{3}{ }^{-}$from the urine as well as increases in titratable acids (i.e., phosphoric acid, creatinine, and uric acid) and ammonium excretion as observed in the present study. Changes in the electrolyte composition of urine in the present study indicate $\mathrm{K}^{+}$and $\mathrm{Na}^{+}$concentrations increased and decreased in the acute and sub-chronic phases, respectively, whereas $\mathrm{Ca}^{2+}$ and $\mathrm{Cl}^{-}$remained increased in both study phases. The fluctuation in urinary $\mathrm{K}^{+}$levels parallels the changes observed in plasma $\mathrm{K}^{+}$levels in both study phases and may signify the effect of the high $\mathrm{K}+$ content of the extract as detected in the present and previous studies $[27,29,45]$ and the role of the kidneys in an adaptive response to a high- $\mathrm{K}^{+}$diet. In an excellent functional state, the excretory response to acute $\mathrm{K}^{+}$load by the kidneys is enhanced, and the associated increase in plasma $\mathrm{K}^{+}$level is mitigated by the preceding period of high $\mathrm{K}^{+}$intake. This adaptive response mechanism is controlled by aldosterone, because such an effect is absent in adrenalectomized animals and is restored by administration of an exogenous mineralocorticoid [40].

Similarly, the patterns of fluctuations in plasma and urinary $\mathrm{Na}^{+}$levels in the present study are consistent with changes in individuals on a high- $\mathrm{K}^{+}$diet as well as electrolyte patterns in animal studies following high $\mathrm{K}^{+}$loading [47], accordingly, 
Young et al. [41], assessed the chronic effect of $\mathrm{K}^{+}$loading on $\mathrm{Na}^{+}$balance and found that increasing daily $\mathrm{K}^{+}$intake increases the plasma $\mathrm{K}^{+}$concentration with a $56 \%$ increase in $\mathrm{Na}^{+}$excretion despite a 58\% increase in plasma aldosterone concentration. The result of the aforementioned study is paradoxical, because an increase in plasma aldosterone caused by increased $\mathrm{K}^{+}$it would be expected to cause $\mathrm{Na}^{+}$re-absorption, thereby reducing excretion.

The plausible explanation for this is the suppressive effect of chronic $\mathrm{K}^{+}$intake on rennin activity $[42,43]$. Moreover, the diuretic and natriuretic effect of a high- $\mathrm{K}^{+}$ diet could explain the urinary electrolyte changes observed in the present study [44]. The decrease of urinary $\mathrm{Na}^{+}$levels in the sub-chronic phase corresponds to a return of plasma $\mathrm{Na}^{+}$to baseline levels within the same period and signifies the transient inhibitory effect of a high- $\mathrm{K}^{+}$diet on the RAAS due to the phenomenon of aldosterone escape [45]. This interaction between $\mathrm{K}^{+}$load (i.e., high- $\mathrm{K}^{+}$diet) and $\mathrm{Na}^{+}$was the focus of Von Bunge's studies in Germany in the mid-1870s and remains a topic of interest to date [46], he was concerned that the natriuresis produced by $\mathrm{K}^{+}$would lead to serious disease. However, the natriuresis fortunately lasted only a few days to one week before $\mathrm{Na}^{+}$balance was restored.

Similarly, Michelson et al. [47] observed that although initial natriuresis occurred as a result of $\mathrm{K}^{+}$administration, $\mathrm{Na}^{+}$balance was generally restored within one week. This effect of $\mathrm{K}^{+}$on $\mathrm{Na}^{+}$excretion is exploited in the management of several diseases associated with high plasma $\mathrm{Na}^{+}$concentrations, including heart failure and hypertension [48]. Increase in urinary $\mathrm{Ca}^{2+}$ concentration indicates impaired reabsorption. Approximately $50 \%$ of plasma $\mathrm{Ca}^{2+}$ is freely filtered via the renal glomeruli, and $99 \%$ of the filtered $\mathrm{Ca}^{2+}$ is reabsorbed along the renal tubules [49]. In addition, approximately 50-60\% of the filtered $\mathrm{Ca}^{2+}$ is reabsorbed along with $\mathrm{Na}^{+}$and $\mathrm{H}_{2} \mathrm{O}$ [49]. Therefore, $C$. citratus may impede $\mathrm{Ca}^{2+}$ reabsorption via 2 potential pathways: (1) through its diuretic actions (i.e., loop-active-like and potassium sparing actions) [50-52] and (2) through associated metabolic acidosis. As a diuretic agent through its bioactive constituents, $C$. citratus interferes with $\mathrm{Na}^{+}$and $\mathrm{H}_{2} \mathrm{O}$ re-absorption by inhibiting the 3-ion co-transport system $\left(\mathrm{Na}^{+} / \mathrm{K}^{+} / 2 \mathrm{Cl}^{-}\right)$[52] and also by blocking the aldosteronesensitive $\mathrm{Na}^{+}$channels located on the cortical collecting tubules [52]. Irrespective of the mechanism, the inhibitory actions of diuretics on $\mathrm{Na}^{+}$and $\mathrm{H}_{2} \mathrm{O}$ re-absorption interfere with the trans-epithelial potential differences associated with the re-absorption of $\mathrm{Na}^{+}$ and water, which are required for $\mathrm{Ca}^{2+}$ re-absorption, leading to hypercalciuria [53].

A recent study suggests acidic $\mathrm{pH}$ increases calciuria by inhibiting the renal epithelial apical $\mathrm{Ca}^{2+}$ channel transient receptor potential $\mathrm{V}_{5}-\left(\mathrm{TRPV}_{5}\right)$ and $\mathrm{TRPV}_{6}-$ mediated $\mathrm{Ca}^{2+}$ re-absorption in the distal nephron [54]. We previously reported that C. citratus possesses both loop-active and K-sparing diuretic actions in humans [52], which corroborates previous hypotheses [50,51] and provides empirical evidence in support of the changes in plasma and urinary $\mathrm{pH}$ and electrolyte excretion observed in the present study. As a loop-active diuretic, C. citratus could impair $\mathrm{Na}^{+}, \mathrm{Cl}^{-}$, and $\mathrm{H}_{2} \mathrm{O}$ re-absorption and secondarily impairs $\mathrm{Ca}^{2+}$ reabsorption. Meanwhile, as a K-sparing diuretic, $C$. citratus could cause metabolic acidosis, hyper-kalemia, natriuresis, and chloruresis [52]. Therefore, the increases in urination frequency, urinary volume, and other diuretic indices including increased fractional excretion of electrolytes in the present study are corollaries of the diuretic actions of $C$. citratus. The strength of this study lies in the careful selection of study participants, including the population size, age (18-35 years), which excludes the confounding effect of age-related changes in renal function, equal sex distribution, which excludes sex-related effects on the examined variables, and study design (interventional design), which controls for individual differences in baseline characteristics. Nevertheless, there are some limitations that warrant recognition, including the inability to measure the plasma activities of the alleged affected enzymes systems involved in acid-base and electrolyte homeostasis, including renin, aldosterone, $\mathrm{Na}^{+}-\mathrm{K}^{+}$ATPase activity and $\alpha \mathrm{ENC}$ mRNA. Thus, future studies should address these concerns to confirm the present findings. 


\section{Conclusion}

The consumption of lemongrass tea may be associated with acid-base derangement and electrolyte wastage in normal individuals through the interactions of some of its phyto-constituents with the body's acid-base and electrolytes homeostatic mechanisms.

\section{References}

1. Blowey DL. Nephrotoxicity of over-the-counter analgesics, natural medicines, and illicit drugs. Adolesc Med. 2005; 16: 31-43. Ref.: https://goo.gl/9SPB7p

2. Ifudu O, Friedman EA. Kidney injury, electrolyte and acid-base abnormalities associated with use of alternative medicine product. Dial Transplant. 2009; 38: 124-127. Ref.: https://goo.gl/yYmDWP

3. Luyckx VA, Steenkamp V, Stewart MJ. Acute Renal Failure Associated With the Use of Traditional Folk Remedies In South Africa. Ren Fail. 2005; 27: 35-43. Ref.: https://goo.gl/cNyz6s

4. Muller BA, Scott MK, Sowinski KM, Prag KA. Noni juice (morinda citrifolia): hidden potential for hyperkalemia. Am J Kidney Dis. 2000; 35: 310-312. Ref.: https://goo.gl/bQdwfD

5. Nagasaki A, Takamine W, Taksu N. Severe hyperalemia associated with "alternative" nutritional cancer therapy. Clinical Nutrition. 2005; 24: 864-865. Ref.: https://goo.gl/xDE5Py

6. Tsai CS, Chen YC, Chen HH, Cheng CJ, Lin SH. An Unusual Cause of Hypokalemia Paralysis: Aristolochic Acid Nephropathy with Fanconi Syndrome. Am J Medical Sciences. 2005; 330: 153-155. Ref.: https://goo.gl/ZsyWYE

7. Cheng CJ1, Chen $\mathrm{YH}$, Chau T, Lin SH. A hidden cause of hypokalemic paralysis in a patient with prostate cancer. Support care cancer. 2004; 12: 810-812. Ref.: https://goo.gl/2C4pMd

8. Ko RJ. Adulterants in Asian patent medicines. New Engl J Med. 1998; 339: 847. Ref.: https://goo.gl/D7t7xQ

9. Haller CA1, Dyer JE, Ko R, Olson KR. Making a diagnosis of herbal related toxic hepatitis. Western Journal of Medicine. 2002; 176: 39-44. Ref.: https://goo.gl/1UWyNJ

10. Lee JJ, Chen HC. Flavonoids-induced acute nephropathy by Cupressus funebris Endl (Mourning cypress). Am J Kidney Dis. 2006; 48: e81-85. Ref.: https://goo.gl/6kjTHu

11. Westendorf ML, Gordon R. Effect of increasing undegradable intake protein when sheep are fed diets low in protein. Prof Anim Sci. 1998; 14: 16-21. Ref.: https://goo.gl/kMMyK2

12. Tarkang PA, Agbor GA, Tsabang N, Tchokouaha RY, et al. Effect of Long-Term Oral Administration of The Aqueous and Ethanol Leaf Extract Of Cymbopogon Citratus (DC. Ex Ness) Stapf. Annals of Biological Research. 2012; 3: 5561-5570.

13. Carlini EA, Contar J de DP, Silva-Filho AR, da Silveira-Filho NG, Frochtengarten ML, et al. Pharmacology of Lemon Grass (Cymbopogon citratus Stapf.): Effects of Teas Prepared from the Leaves on Laboratory Animals. J Ethnopharmacol. 1986; 17: 37-64. Ref.: https://goo.gl/P5Lo1F

14. Nambiar VS, Matela H. Potential function of lemongrass (Cymbopogon citratus) in health and disease. Int J Pharm Biol Arc. 2012; 3: 1035-1043. Ref.: https://goo.gl/KES43R

15. Ekpenyong $\mathrm{CE}$, Daniel $\mathrm{NE}$, Atai $\mathrm{AB}$. Effect of Lemongrass tea consumption on estimated glomerular filtration rate and creatinine clearance rate. J Renal Nutrition. 2015; 25: 57-66. Ref.: https://goo.gl/n6Yt3E

16. Ferreira MS, Fonteles MC. Aspectos etnobotanicos efarma cologicos do Cymbopogon citratus staph (capim limao). Revita Brasileira de Farmacia. 1989; 70: 94-97.

17. Tzortzakis NG, Economakis CD. Antifungal activity of lemongrass (Cymbopogon citratus) essential oil against key pst-harvest pathogens. Innov Food Sci Emerg (IFSET). 2007; 8: 253-258. Ref.: https://goo.gl/jbspN1

18. Paranagama PA, Abeysekera KHT, Abeywickrama $K$, Nugaliyadde L. Fungicidal and anti-aflatoxigenic effects of the essential oil of Cymbopogon citratus (DC.) Stapf. (lemongrass) against Aspergillus flavus Link. isolated from stored rice. Lett Appl Microbiol. 2003; 37: 86-90. Ref.: https://goo.gl/Aj1fuf

19. Leite JR, Seebra MV, Maluf E, Assolant K, Suchecki D, et al. Pharmacology of lemongrass (Cymbopogon citratus) 111. Assessment of eventual toxic; hypnotic and anxiolytic effects on humans. J Ethnopharmacol. 1986; 17: 75-83. Ref.: https://goo.gl/8q3vBm

20. Lahlou S, Figueiredo AF, Magalhoes PJ, Leal-Cardoso JH. Cardiovascular effects of 1, 8-cineole, a 
terpenoid oxide present in many plants essential oil in normotensive rats. Can J Physiol Pharmacol. 2007; 80: 1125-1131. Ref.: https://goo.gl/baWfXz

21. Wright $\mathrm{Cl}$, Van-Buren L, Kroner $\mathrm{Cl}$, Koning MM. Herbal Medicines as Diuretics: A review of scientific evidence. J Ethnopharmacol. 2007; 114: 1-31. Ref.: https://goo.gl/758NT4

22. Pauler PE and Zubeita-Calleja OR. Essential in the Diagnosis of Acid-Base Disorders and Their High Altitude Application. Journal of Physiology and Pharmacology. 2005; 56, Suppl 4: 155-170. Ref.: https://goo.gl/B4UZGA

23. Schwalfenberg GK. The Alkaline Diet: Is There Evidence That an Alkaline Ph Diet Benefits Health? J Environ Public Health. 2012; 2012:727630. Ref.: https://goo.gl/jzAcP6

24. Oloyede IO. Chemical profile and antimicrobial activity of Cymbopogon citratus leaves. Journal of Natural Product. 2009; 2: 98-103. Ref.: https://goo.gl/Ni2F65

25. Vendruscolo GS, Maris S, Rates K, Mentz LA. Chemical and pharmacologic data on medical plants used by the community of the Ponta Grossa neighborhood, Porto Alegre, Rio Grande do Sul, Brazil. Brazilian Journal of Pharmacognosy. 2005; 15: 361-372. Ref.: https://goo.gl/jwyk4S

26. Aftab K, Ali MD, Aijaz P, Beena N, Gulzar HJ, et al. Determination of different trace and essential element in lemongrass samples by $\mathrm{x}$-ray fluorescence spectroscopy technique. Int Food Res J. 2011; 18: 265-270. Ref.: https://goo.gl/uP5SY7

27. de Souza, De Souza AM, Lara L, Previato JO, Lopesa AG, et al. Modulation of sodium pumps by steroidal saponins. Z Naturforsch C. 2004; 59: 432-436. Ref.: https://goo.gl/3PLDFu

28. Rhiouani H, Settaf A, Lyoussi B, Cherrah $Y$, Lacaille-Dubois MA et al. Effects of sap on ins. from Hemiaria glabra on blood pressure and renal function in spontaneously hypertensive rats. Therapie. 1999; 54: 735-739. Ref.: https://goo.gl/kPmwrQ

29. Jouad H, Haloui M, Rhiouani H, El Hilaly J, Eddouks M. Ethnobotanical survey of medicinal plants used for the treatment of diabetes, cardiac and renal diseases in the North centre region of Morocco (Fez-Boulemane). J Ethnopharmacol. 2001; 77: 175-182. Ref.: https://goo.gl/fEcFjk

30. Hiwatashi K, Shirakawa H, Hori K, Yoshiki Y, Suzuki N, et al. Reduction of blood pressure by Soya bean saponins, Rennin inhibitors from Soya bean, in spontaneously hypertensive Rats. Bioscience Biotechnology Biochemistry. 2010; 74: 2310-2312.

31. Chen $\mathrm{M}$, Long $\mathrm{Z}$, Wang $\mathrm{Y}$, lu J, Pian $\mathrm{H}$, et al. Protective effect of Saponin on a hypertension target organ in spontaneously hypertensive rats. Exp Ther Med. 2013; 5: 429-432. Ref.: https://goo.gl/Dw9AT8

32. Giovannucci E, Liu Y, Hollis BW, Rimm EB. 25-Hydroxyvitamin D and Risk of Myocardial infection in men: a prospective study. Arch of Int. Medicine. 2008; 168: 1774-1180. Ref.: https://goo.gl/Jg2mqP

33. Aoi W, Niisalo N, Miyazaki H and Marunaka Y. Flavonoid-Induced Reduction of ENAC Expression in the Kidney of Dahl Salt-Sensitive Hypertensive Rat. Biochem Biophys Res Commun. 2004; 315: 892896. Ref.: https://goo.gl/3x47Cd

34. Akande IS, Samuel TA, Agbazue U, Olowolagba BL. Comparative Proximate Analysis of Ethanolic and Water Extracts of Cymbopogon citratus (Lemon grass) and Four Tea Brands. Plant Sciences Research. 2011; 3: 29-35. Ref.: https://goo.gl/jvwwLv

35. Arhoghro EM, Kpomah ED. Cymbopogon citratus aqueous extract alleviates cisplatin-induced renal oxidative stress and toxicity in albino rats. American Journal of Research Communication. 2013; 3: 100-125. Ref.: https://goo.gl/D631SA

36. Mardon J, Habauzit V, Trzeciakiewiucz A, Davicco MJ, Lebecque $P$, et al. Long-term intake of a high protein diet with or without potassium citrate modulates acid-base metabolism, but not bone status, in male rats. J Nutr. 2008; 138: 718-724. Ref.: https://goo.gl/TW3b2L

37. Erdmann $\mathrm{K}$, Cheung B, Schröder $\mathrm{H}$. The possible roles of food derived bioactive peptides in reducing the risk of cardiovascular disease. J Nutr Biochem. 2008; 19: 643-654. Ref.: https://goo.gl/NrKxXf

38. Farooqi ZR, Iqbal MZ, Shafiq M. Toxic effects of lead and cadmium on germination and growth of Albizia lebbeck (L.) Benth. Pak J Bot. 2009; 41: 27-33. Ref.: https://goo.gl/hu4in3

39. Pizzorno J, Frassetto LA, Katzinger J. Diet-Induced Acidosis: Is It Real and Clinically Relevant? $\mathrm{Br} \mathrm{J}$ Nutr. 2010; 103: 1185-1194. Ref.: https://goo.gl/PHAK2M

40. Adam WR, Dawborn JK. Potassium Tolerance in Rats. Aust J Exp Biol Med Sci. 1972; 50: 757-768. Ref.: https://goo.gl/hqP8Rr

41. Young DB, Mccaa RE, Pan Y, Guyton AC. The Natriuretic and Hypotensive Effects of Potassium. Circ Res. 1976; 38 (Suppl II): 84-89. Ref.: https://goo.gl/VfsZi1 
42. Dluhy RG, Underwood RH, Williams GH. Influence of Dietary Potassium on Plasma Rennin Activity in Normal Man. J Appl Physiol. 1970; 28: 299-302. Ref.: https://goo.gl/R8g1f4

43. Flamenbaum WTA, Kotchen RN, Mcneil JD. Effect of Potassium on the Rennin-Angiotensin System and $\mathrm{Hgcl}_{2}$ Induced Acute Renal Failure. American Journal of Physiology. 1973; 224: 305-311. Ref.: https://goo.gl/yrTNYC

44. Brunner HR, Baer L, Sealey JE. The Influence of Potassium Administration and Deprivation on Renin in Normal and Hypertensive Subjects. J Clin Invest. 1970; 49: 2128-2138. Ref.: https://goo.gl/uCfZMG

45. Wenzel U. Aldosterone Antagonist: Silver Bullet or just Sodium Excretion and Potassium Retention? Kidney Int. 2007; 71: 374-376. Ref.: https://goo.gl/EqQc2H

46. Von Bunge G. Concerning the Significant Of Table Salt in the Human Organism. Zeitschrift Fur Biologie. 1873; 9: 104-143.

47. Michelson O, Makdani D, Gill JL, Frank RL. Sodium and Potassium Intakes and Excretions of Normal Men Consuming Sodium Chloride or a 1:1 Mixture of Sodium and Potassium Chlorides. American Journal of Clinical Nutrition. 1977; 30: 2033. Ref.: https://goo.gl/ugR5Lu

48. Treasure J, Ploth D. Role of Dietary Potassium in the Treatment of Hypertension. Hypertension. 1983; 5:864-872. Ref.: https://goo.gl/MuLxUt

49. Jeon US. Kidney and calcium homeostasis. Electrolyte and bllod pressure. 2008; 6: 68-76. Ref.: https://goo.gl/dDTk5v

50. Carbajal D, Casaco L, Arruzazabala L, Gonzalaz R, Tolon Z. Pharmacological study of Cymbopogon citratus leaves. J Ethnopharmacol. 1989; 25: 103-107. Ref.: https://goo.gl/3yXsQ7

51. Caluscusin IR. The effect of twice-aday intake of lemon grass decoction among hypertensive individuals in Barangay Situbo, municipality of Tampilis province of Zamboangadel Norte. ADZU SOM 2010; Ref.: https://goo.gl/BUvzdw

52. Ekpenyong C, Daniel N, Akpan E. Phytoconstituents and diuretic activity of Cymbopogon citratus leaf infusions in humans. J Coastao Life Med. 2014; 2:704-713. Ref.: https://goo.gl/Xn4u7P

53. Moe OW, Huang CL. Hypercalciuria from Acid Load: Renal Mechanisms. J Nephrol. 2006; 19 : 53-61. Ref.: https://goo.gl/nhKydQ

54. Yeh BI, Kim YK, Jabbar W, Huang CL. Conformational Changes of Pore Helix Coupled to Gating Of TRPVS By Protons. European Molecular Biology Organization Journal. 2005; 24: 3224-3234. Ref.: https://goo.gl/HKY1Qw 